\title{
How Institutionalized Are Model License Use Terms? An Analysis of E-Journal License Use Rights Clauses from 2000 to 2009
}

\section{Kristin R. Eschenfelder, Tien-I Tsai, Xiaohua Zhu, and Brenton Stewart}

This paper explored the degree to which use terms proposed by model licenses have become institutionalized across different publishers' licenses. It examined model license use terms in four areas: downloading, scholarly sharing, interlibrary loan, and electronic reserves. Data collection and analysis involved content analysis of 224 electronic journal licenses spanning 2000-2009. Analysis examined how use terms changed over time, differences between consortia and site license use terms and differences between commercial and noncommercial publisher license use terms. Results suggest that some model license use terms have become institutionalized while others have not. Use terms with higher institutionalization included: allowing ILL, permitting secure e-transmission for ILL, allowing e-reserves with no special permissions, and not requiring deletion of e-reserves files. Scholarly sharing showed lower institutionalization with most publishers not including scholarly sharing allowances. Other use terms showing low institutionalization included: recommendations to avoid printing requirements related to ILL and recommendations to allow hyperlinks for e-reserves. The results provide insight into the range of use terms commonly employed in e-journal licenses.

\section{Introduction}

The exchange of electronic resources, like e-journals, between publishers and libraries are typically governed by license agreements. The negotiation of license terms, including terms of use, is a standard part of licensing practice. ${ }^{1}$ The terms of use dictate acceptable and

Kristin R. Eschenfelder is a Professor in the School of Library and Information Studies at the University of Wisconsin-Madison, e-mail: eschenfelder@wisc.edu; Tien-I Tsai is a PhD student at the University of Wisconsin-Madison, email ttsai5@wisc.edu; Xiaohua Zhu is an Assistant Professor at the School of Information Sciences, University of Tennessee-Knoxville, email: xzhu12@utk.edu; Brenton Stewart is an Assistant Professor at the School of Library \& Information Science, University of Southern Mississippi, email: Brenton. Stewart@USM.edu. Special thanks to Ted Bergstrom for sharing his data set. Thank you to the CERL reviewers for their insightful suggestions. The following individuals provided feedback on versions of this paper: Ken Frazier, Ed Van Gemert, Sara Gold, Sook Lim, Eric Robinson, Alan Rubel, Sara White, Mike Xenos and the students of LIS 755. This research was funded by Institute of Museum and Library Services Laura Bush 21st Century Research Grant RE-04-06-0029-06. (C) 2013 Kristin R. Eschenfelder, Tien-I Tsai, Xiaohua Zhu, and Brenton Stewart, Attribution-NonCommercial (http://creativecommons.org/licenses/by-nc/3.0/) CC BY-NC. 
unacceptable ways of using the e-journal materials on publishers' Web-based platforms; for example, can users e-mail a PDF of an article to a collaborator at another institution, or must libraries print out e-journal articles before transmitting them for interlibrary loan?

Studies of electronic resource use terms are important for several reasons. Studies tracking use rights over time will illuminate how those rights have changed as license-based business models have increased. These data will inform library communities' concerns about potential erosion of use rights under licensing models. Further, some have suggested that use of licenses to govern the exchange of e-resources between libraries and publishers is unsustainable, and efforts are under way to develop licensing alternatives. ${ }^{2}$ Knowing how stakeholders currently employ use terms is imperative to development of alternative exchange governance mechanisms. Finally, licensing studies can facilitate negotiations by increasing the negotiating parties' knowledge of the range of use terms employed in the field. Finally, licensing study data spotlight troublesome use terms that persist in at least some publishers' licenses, encouraging further action to modify those terms.

Licensing is a micro and macro social process in which stakeholders shape use terms to their (and their constituents') benefit. At a micro level, licensing librarians and publisher representatives negotiate to achieve terms favorable to their institutions. At a macro level, library and publisher organizations seek to influence what use terms end up in licenses by producing and circulating materials that present certain terms as legitimate or a desirable standard operating procedure. For example, library organizations produce model licenses that recommend use terms favorable to libraries and library patrons. Model licenses are publicized and promoted as best practice in licensing education and professional materials. ${ }^{3}$ The first model licenses appeared in the late 1990s with the publication of the International Coalition of Library Consortia (ICOLC) Statement of Current Perspective and Preferred Practices for the Selection and Purchase of Electronic Information. There are several well-known contemporary library model license agreements - for example, the Liblicense model license ${ }^{4}$ and the ICOLC Preferred Practices. ${ }^{5}$ In addition, some libraries or consortia publish their own standards such as the CIC Standardized Agreement. ${ }^{6}$

Publisher associations also influence use terms through production of claims about what use terms ought to be accepted by libraries and publishers. For example, the Association of Scientific Technical and Medical Publishers recently made new claims about what use terms ought to govern interlibrary loan-suggesting that receiving libraries should only deliver interlibrary loan articles to end users in paper formats. ${ }^{7}$ Publishers also shape use terms through creation of what this paper calls publisher "standard licenses." Publishers use standard licenses to begin negotiations. Standard licenses provide a default set of terms that negotiation might seek to modify. If no changes are made during negotiation, the standard license terms govern the agreement. This paper refers to the outcome of a library-publisher negotiation as a "final license." The final license arguably is influenced by both the publisher's standard license and use terms promoted by library model licenses.

Model licenses, licensing statements, and standard licenses are attempts by stakeholders to institutionalize certain use terms as standard operating procedures or-even stronger-as values to which everyone ought to adhere. "Institutionalization," as described by organizational theorists like Richard Scott, is a process whereby actors push for certain values to become so widely accepted they are taken for granted across all relevant stakeholders in a field. In intermediate stages of the process, not all stakeholders may agree, and some may promote alternative 
processes or values. ${ }^{8}$ We see use terms as temporary outputs in an institutionalization process. Use terms reflect different stakeholders' views about what rights users ought to have. ${ }^{9}$ A given use term may be more or less institutionalized depending on how taken for granted it is by all stakeholders in a field.

In this study, we examine the degree to which certain use terms have become institutionalized across libraries and publishers. We define level of institutionalization of use terms as the degree to which they are present or absent in final licenses. We focus on use terms recommended by model licenses and examine whether they appear in final licenses. High institutionalization of a term is evidenced by a greater percentage of final licenses using the term. Conversely, low institutionalization is evidenced by low use of a given use term in final licenses. This study also examines how use terms have changed over time and examines differences in use terms across individual publishers, across publisher types (commercial vs. noncommercial), and between license types (site vs. consortium).

Findings are based on analysis of 224 e-journal final licenses from the period 2000-2009. The licenses were collected via open records requests by Bergstrom, Courant, and McAfee for a study of journal pricing. ${ }^{10}$ The licenses represent 11 publishers and 52 different public universities including 10 consortia.

We analyzed sets of use terms from four areas: (a) downloading, (b) scholarly sharing, (c) electronic reserves, and (d) interlibrary loan. We examined each use term in light of model licenses recommended use terms. For each use term, we explored the following:

1. Did the use terms change over time? Analysis sought to discover whether model license recommendations became more institutionalized over the time period of the study (2000-2009).

2. Did use terms vary between site and consortia licenses? ${ }^{11}$ We ana- lyzed whether consortia's greater bargaining power meant that model license recommended use terms were more institutionalized in consortia licenses.

3. Did use terms vary between commercial and noncommercial publishers? Analysis compared levels of institutionalization of model license recommended use terms in the licenses of commercial and noncommercial publishers.

4. How did use terms vary by publisher? Analysis sought to rank individual publishers in terms of the degree to which model license recommendations were institutionalized in the publisher's licenses.

Prior studies have examined several different types of license data:

- Publisher standard license: The license text offered by a publisher at the start of a negotiation process. This license may be posted on the publisher website. If no negotiation occurs, or publishers refuse to modify terms, then the standard license terms govern the agreement. $^{12}$

- Reported license terms: Reports of what use terms licenses contain based on indirect measures such as surveys or interviews with license negotiators. ${ }^{13}$

- Final license: The output of the negotiation process based on the standard license but including edits if edits occurred. Several licensing studies provide final license data, but most report on data from just the authors' institutions. ${ }^{14}$

This study of final licenses includes a much larger set of licenses than prior studies. Data span 52 different libraries while most prior studies rely on final licenses from just a few institutions or employ standard licenses posted on publisher websites. Further, this study analyzes a different set of use terms (for instance, print first requirements for ILL, 
hyperlinks for e-reserves) than previous studies, and it includes a different set of publishers. It includes licenses from more recent time periods (after 2006). Finally, this study is one of few to report final license results at the individual publisher level. Many studies only report publisher specific results from standard licenses or from group level data (such as by time period or publisher type) from final licenses.

We found that the majority of final licenses in this study deviated from library model license best practices by not including fair use clauses, by including print requirements for ILL, by not permitting ILL for commercial users and by not permitting e-reserves hyperlinks. Examining use terms over time, our data show statistically significant increases in the percent of licenses recognizing scholarly sharing, permitting e-reserves, and permitting hyperlinks in e-reserves. We found that consortia licenses were significantly less likely to prohibit e-distribution, and to permit e-reserves; but, consortia licenses were more likely to include the print-first requirement in ILL. Our results show that, in general, noncommercial licenses accommodated fewer model license best practices than commercial licenses.

The next section continues by providing an overview of what we already know about use terms related to downloading, scholarly sharing, interlibrary loan, and electronic reserves.

\section{Downloading and Fair Use}

Downloading restrictions have been around since the early 1980s. ${ }^{15}$ From a publisher perspective, downloading is risky because downloaded articles could substitute for a subscription, and excessive use could overwhelm publishers' infrastructures. Previous studies provide limited information on downloading use rights. Farb's study examined publisher standard licenses for restrictions on downloading and found that all contained downloading restrictions. ${ }^{16}$ While Farb did not report the nature of the downloading restrictions, licensing manuals suggest licenses forbid systematic and extensive downloading. ${ }^{17}$

Model licenses like the Liblicense and the ICOLC model license recommend inclusion of fair use clauses, but some publishers might resist. ${ }^{18}$ One original rationale for adopting licensing in the early $1980 s^{\prime}$ transition to electronic publishing was that licenses could preclude fair use claims. ${ }^{19}$ As one publisher interviewed by Farb noted, "In theory, no fair use $=$ why we license." ${ }^{20}$ Farb found that only about one-third of the commercial, scholarly, and university publisher standard licenses she examined contained a fair use clause. Commercial publishers not including fair use rights in standard licenses included BLW, ELV, T\&F, and WLY. ${ }^{21}$ Farb also surveyed 114 library licensing units and asked what percent of final licenses included fair use clauses. Respondents reported that they believed about 75 percent of their final licenses included fair use provisions. ${ }^{22}$

\section{Scholarly Sharing}

Scholarly sharing is the peer-to-peer sharing of e-resources such as e-journal articles between colleagues across institutional boundaries without the mediation of a library. Licenses typically define scholarly sharing as occasional and nonsystematic sharing of insubstantial amounts of content with colleagues or research partners at other institutions for noncommercial purposes. Model licenses encourage inclusion of scholarly sharing clauses. For example, the Liblicense model license suggests the following language: "Authorized Users may transmit to a third party colleague... minimal, insubstantial amounts of the Licensed Materials for personal, scholarly, educational, scientific, or research uses." ${ }^{23}$ From a publisher perspective, scholarly sharing is a concern because extensive sharing could discourage new subscriptions, and any sharing could substitute for one-off article purchases.

Past studies suggest publisher resistance to scholarly sharing. Farb examined 
standard licenses for a scholarly sharing right and found that one-third of her commercial and society standard licenses and all her university press standard licenses included it. ${ }^{24}$ At that time, the commercial standard licenses not including scholarly sharing rights included BLW, ELV, and WLY. Davis and Feather's analysis of 2006 final licenses found that more licenses prohibited scholarly sharing (48.6\%) than permitted it $(28.6 \%)$, but that many were silent on scholarly sharing $(22.9 \%) .^{25}$

\section{Interlibrary Loan}

Interlibrary loan (ILL) is the "practice of one library (the receiving library) placing a request on behalf of one of its users with another library (the fulfilling library) for materials that the requesting library does not possess or have immediately available." ${ }^{26}$ In this study, we focused on ILL related to e-journal articles.

In the early development of e-journals, it was unclear if publishers would allow ILL from electronic databases. A 1997 Liblicense-L poll asked whether publishers ought to permit ILL for databases. Not surprisingly, librarians overwhelming voted yes, but two-thirds of the responding publishers voted no. ${ }^{27}$ Previous license studies suggest that ILL became more common in the mid 2000s, but problems still existed. A 2003 ARL study of 14 publishers' licenses found variance within each publisher's set of licenses-given publisher $\mathrm{X}$, some $X$ licenses permitted ILL from e-journals while others did not. But most of their 14 publishers (but not ELV) allowed it in at least some instances. ${ }^{28}$ Davis and Feather reported that 25.7 percent of mostly noncommercial 2006 licenses still prohibited ILL. ${ }^{29}$ Farb's review of standard licenses found ELV still did not permit ILL, but her 3 university press licenses permitted ILL. Further, Farb's survey of librarians found that many still perceived ILL restrictions as problematic. ${ }^{30}$

Another area of debate is whether publishers will allow for use of secure e-delivery systems for ILL articles. Not permitting secure e-delivery means that the fulfilling library must send the article via fax or paper mail, slowing down the process. Some model licenses specifically call for inclusion of secure e-delivery mechanisms. ${ }^{31}$

A separate but related debate in ILL is print requirements. Under "print-first" requirement, publishers require that the fulfilling library prints a copy of the requested e-article before scanning the article to make a new digital copy that is then sent to the receiving library through a secure e-transmission system. Under the second type, "print delivery," publishers require that receiving libraries only provide print-not electronic-delivery to requesting patrons. Under this vision, the requesting user would need to travel to the receiving library to obtain her paper request or wait for delivery via paper mail. ${ }^{32}$

Some publishers may include print requirements if they believe that ILL threatens markets for article delivery by offering "de facto universal on-demand access" to materials from other institutions. ${ }^{33}$ The print requirement protects document delivery services by slowing down ILL processes and making ILL more expensive for libraries to support. Print requirements place "friction in the system," creating an upper limit on how much libraries are willing to borrow and lend. ${ }^{34}$ Davis \& Feather reported that 46 percent of mostly noncommercial licenses only permitted print-based ILL (such as paper mail, fax). ${ }^{35}$ Model licenses like the CIC and Liblicense model license encourage removal of print-first or print-delivery requirements by offering alternative text that does not mention printing or paper. ${ }^{36}$

\section{Electronic Reserves}

Electronic reserves (e-reserves) has always been contentious, and the recent cases brought against Georgia State University and University of California San Diego for e-reserves practices show debates about e-reserves are ongoing. ${ }^{37}$ E-reserves practice is based on fair use claims or Section 107 of Copyright Law. 
But the highly interpretable nature of fair use means that the law provides little explicit guidance about what can be put on e-reserves. ${ }^{38}$

Parties even disagree about whether ereserves fall under the control of licenses or not. Some charge that e-reserves are only permissible if explicitly allowed by license language. In this view, placing an article on e-reserves requires explicit recognition in a license. Many model licenses recommend explicit inclusion of e-reserves in license text. Others argue, however, that licensing a product gives one the right to use articles in e-reserves (within the bounds of fair use) even if the license doesn't explicitly permit ereserves. As Goodman argued on Liblicense-1 in 2000, "If you have a license that provides access to all the members of an institution to all the articles in a journal... this inherently and automatically includes the use of a subset of articles by a subset of the students. Any statement permitting the use of e-reserves in a site license is unnecessary and redundant." 39

Some envisioned e-reserves permissions and fees as a revenue generator for publishers. For example, the Copyright Clearance Center's best practices for e-reserves notes, "the institution must obtain permission from the rights holder .. who may charge a fee for such permission." 40

Past examinations of licenses found that many licenses were silent about ereserves. In 2001, Hatfield found that few publishers had formal policies available for analysis. ${ }^{41}$ Studies from the mid 2000s still found that most licenses were silent on e-reserves or did not include an explicit e-reserves right, but Farb's work suggests that, by 2005, some noncommercial publisher standard licenses recognized e-reserves. ${ }^{42}$ Model licenses urge inclusion of language that explicitly allows e-reserves without any extra permissions or fees. ${ }^{43}$

Another e-reserves debate is whether permission is required for libraries to create proxy-protected hyperlinks to full-text documents in a publisher database, also known as "deep linking." Some publish- ers have also expressed concern that the convenience of deep linking in e-reserves might discourage textbook or paper course packs sales. ${ }^{44}$ No prior licensing study has examined linking permissions. Model licenses suggest text to allow deep linking. For example, the Liblicense model suggests: "Licensee may provide password- or proxy-protected hyperlinks from the Licensor's Web page(s) or Web site(s) to the Licensed Materials." 45

A related question is whether licenses require libraries to delete e-reserves files immediately after use-typically seen as the end of the course. Not requiring deletion of files could reduce library work if authorized articles are regularly reused in classes. The CIC model license recommended text encourages inclusion of the deletion requirement for articles included in courseware. ${ }^{46}$

\section{Methods}

The final licenses analyzed in this paper were collected by Bergstrom, Courant, and McAfee for a study of journal pricing. ${ }^{47}$ Bergstrom obtained the licenses using state open records laws. He requested licenses from 86 universities and 10 consortia across 47 states. He obtained 224 licenses from 38 universities and 8 consortia from across 28 states, representing agreements with 11 large publishers. The responses are almost exclusively from large universities. ${ }^{48}$ Bergstrom's data set does not represent a random sample; however, it is a useful representation of large state university license agreements.

We categorized the licenses into two sets: commercial/noncommercial publisher licenses and site/consortia licenses. While prior research suggested differences between society and university press publishers, we did not have enough examples to make this distinction, so we combined society and university press publishers into one "noncommercial" group. We counted multicampus state systems as consortia.

We divided the licenses into two time periods: early (2000-2005) and later 
(2006-2009). License dates represent the date of agreement, not the date of creation of the license text or the duration of the license terms. Further, a license initially written in 2003 might be resigned in 2006 with no changes. In this case, the license was coded by the date of last signing (2006) not the date of initial preparation of the contract terms. New licenses prepared by the publisher during the period might include newer terms, but resigned older licenses may keep older terms. ${ }^{49}$

\section{Content Analysis}

The study team employed the content analysis methodology, which provided means to systematically code the license text and suggested statistical tests to ensure uniformity of coding across team members. ${ }^{50}$ We coded licenses using a codebook we developed using standard publisher licenses posted on the Web and refined using subsamples of licenses from the study license set. As part of the codebook, we developed coding rules to manage the "strategically vague" language often found in licenses. Our coding rule of thumb was to code the license as literally as possible; however, some use terms required us to create interpretive rules. ${ }^{51}$ The codebook and coding rules went through 28 revisions over the course of codebook development period.

We conducted coder training to ensure consistency of coding. Training involved subsets of licenses from all 11 publishers and licenses from different time periods. All coders fully participated in coder training. We then tested whether training generated consistent coding across coders by computing an intercoder reliability score (ICR) during official pretests. ${ }^{52} \mathrm{We}$ computed an ICR score for each variable in formal pretests using ReCal to generate percent agreement ICR scores. ${ }^{53}$

Use of percent agreement for ICR is appropriate for this study, given that most variables were coded in a binary manner as present or absent (1 present/0 absent), and that the vast majority of variables received a zero. Content analysis methodologists suggest that, for data sets where most variables receive a 0 , percent agreement ICR is acceptable because other measures of ICR undervalue agreement. ${ }^{54}$ We achieved our target of a minimum 90 percent ICR across all variables in November of 2010 .

After the final pretest, the study team began content analysis of the full data set. Each coder coded 50- 60 licenses. In analyzing each license, the unit of study was the blocks of text within licenses that addressed downloading, fair use, ILL, or e-reserves. Blocks of text ranged from single lines to multiple paragraphs. Coders read the entire license, but only coded blocks of text relevant to the study focus. Importantly, if a license included multiple sets of use terms for multiple products (some licenses included separate e-book use terms), we only analyzed the e-journal package use terms. (A summary of codebook questions is available in Appendix A.)

\section{Analysis: Statistical Tests for Group Differences}

We imported the coding data into SPSS and ran descriptive statistics and significance tests. We tested for statistically significant differences in final license use terms between the following groups: (a) licenses from early and later time periods; (b) consortial vs. site licenses; and (c) commercial publisher vs. noncommercial publisher licenses. We listed percentages for each group in tables to ease casual comparison across groups. We employed the chi-square test to test for statistically significant differences between the groups.

While percentages show differences across groups, the chi-square test shows that the differences are "statistically significant." This means that the observed difference is most likely related to the group category (for instance, earlier vs. later time period or nonprofit vs. commercial license) and not to chance variation. For example, while a table may show a 
difference in percentages between commercial licenses and noncommercial licenses, the chi-square test provides strong evidence that the observed difference is most likely related to the commercial or noncommercial nature of the license. Reported statistically significant results should be read with caution however given the variation within each group: Results from groups with high intragroup variation are less trustworthy than results from groups with low intragroup variation. ${ }^{55}$ A statistically significant finding can still be a spurious finding. Another limitation is that it is not possible to run a chi-square test for table cells with less than five values. We therefore could not run chi-square tests for the publisherlevel data.

\section{Findings}

In reporting the results, we highlight statistically significant differences between groups, but we also point out interesting extremes and trends that are not statistically significant but still interesting.
We observed three types of variation within each publisher's set of licenses. First, we saw expected change. Each publisher tended to have a standard license format that became easily recognizable during analysis. We saw two or three different standard licenses per publisher. The second variation we observed was edits to licenses stemming from negotiation. For example, some licenses would have handwritten notes in margins. The third type of variation we observed is harder to explain. In some cases, we saw what seemed to be oneoff rogue licenses. These solitary licenses differed from all the other copies of the publisher's license in use during the same time period in terms of font, formatting, and use terms.

Throughout the findings section, we use the publisher abbreviations introduced in table 1.

The data set contained 75 site $(33 \%)$ and 149 consortia $(67 \%)$ licenses $(\mathrm{N}=224)$. Most licenses came from the later (20062009) period. Commercial publishers dominated the sample with 186 licenses

\begin{tabular}{|c|c|c|c|c|}
\hline \multicolumn{5}{|c|}{$\begin{array}{c}\text { TABLE } 1 \\
\text { Licenses by Publisher and Year }\end{array}$} \\
\hline & \multicolumn{4}{|c|}{ Commercial Publisher Licenses $\mathrm{N}=186$} \\
\hline & $\begin{array}{c}\text { Total } \\
\text { Licenses } \\
\#\end{array}$ & $\begin{array}{c}\text { Consortium } \\
\text { Licenses } \\
\%\end{array}$ & $\begin{array}{c}\text { 2000-2005 } \\
\#\end{array}$ & $\begin{array}{c}\text { 2006-2009 } \\
\#\end{array}$ \\
\hline Wiley (WLY) & 26 & 88.46 & 10 & 16 \\
\hline Blackwell $(B L W)$ & 18 & 33.33 & 7 & 11 \\
\hline Wiley-Blackwell (WBL) & 16 & 68.75 & - & 16 \\
\hline Elsevier $(E L V)$ & 47 & 68.08 & 11 & 36 \\
\hline Emerald (EMR) & 30 & 80.00 & 8 & 22 \\
\hline Sage (SGE) & 15 & 66.66 & - & 15 \\
\hline Taylor \& Francis $(T \& F)$ & 8 & - & 1 & 7 \\
\hline \multirow[t]{2}{*}{ Springer $(S P R)$} & 26 & 92.31 & 6 & 20 \\
\hline & \multicolumn{4}{|c|}{ Noncommercial Publisher Licenses $\mathbf{N}=\mathbf{3 8}$} \\
\hline American Chemical Society (ACS) & 16 & 37.5 & 11 & 5 \\
\hline Oxford University Press (OUP) & 14 & 64.29 & 4 & 10 \\
\hline Cambridge University Press (CUP) & 8 & 50.00 & 3 & 5 \\
\hline Total & 224 & 66.51 & 61 & 163 \\
\hline
\end{tabular}




\begin{tabular}{|l|c|c|c|c|}
\hline \multicolumn{7}{|c|}{ TABLE 2 } \\
Downloading Restrictions over Time \\
\hline & $\mathbf{2 0 0 0 - 2 0 0 5}$ & $\mathbf{2 0 0 6 - 2 0 0 9}$ \\
\cline { 2 - 6 } & $N=61$ & $\%$ & $N=163$ & $\%$ \\
\hline Does not address below restrictions & 0 & 0 & 6 & 3.68 \\
\hline Forbids systematic or automated downloading & 41 & 67.21 & 98 & 60.12 \\
\hline Limits reproduction to personal use & 50 & 81.96 & 117 & 71.78 \\
\hline Refers to fair use or copyright law & 7 & 11.48 & 27 & 16.56 \\
\hline
\end{tabular}

(83\%). The percent of consortia and site license varied by publisher; table 1 shows that the sample contained no T\&F consortia licenses but that over 60 percent of WLY, WBL, OUP, SPR, SGE, EMR, and ELV licenses were consortia licenses.

\section{Downloading}

Our downloading findings confirm licensing handbooks' suggestion that publishers restrict "systematic" and/or "excessive" downloading, or that publishers might limit downloading to "personal use." As seen in table 2, we found no statistically significant difference in the use of either of these restrictions over time.

We found three other statistically significant differences in treatment of downloading. First, we found site licenses were more likely to include a restriction on systematic or automated downloading than consortia licenses ( $71 \%$ to $58 \%$ ), while both types were equally likely to include the personal use restriction.

As shown in table 4, the majority of noncommercial and commercial licenses included a downloading restriction of some type, but commercial publishers were significantly less likely to do so. The lower level of use by commercial publishers may stem from the fact that a modest portion of WBL and T\&F licenses did not include either downloading restriction (see table 6).

While these differences are statistically significant, we do not think the differences mean much, because both sets of publishers were highly likely to include at least one of the limitations.

We also tracked what percent of licenses referred to fair use in relation to downloading restrictions. Only SPR and $\mathrm{T} \& \mathrm{~F}$ included the fair use reference $(96 \%$ and $75 \%$ of their licenses respectively). No other publishers consistently did so.

\section{Scholarly Sharing}

Licenses commonly recognize scholarly sharing by limiting potential external e-distribution of articles to scholarly sharing situations. In analyzing scholarly sharing, we looked to see if this scholarly sharing limitation was mentioned in licenses ("limits e-distribution to scholarly

TABLE 3

Downloading Restrictions by License Type

\begin{tabular}{|l|c|c|c|c|}
\hline \multirow{2}{*}{} & \multicolumn{2}{|c|}{ Site } & \multicolumn{2}{c|}{ Consortium } \\
\cline { 2 - 5 } & $\mathrm{n}=75$ & $\%$ & $\mathrm{n}=149$ & $\%$ \\
\hline Does not address below restrictions & 4 & 5.33 & 2 & 1.34 \\
\hline Forbids systematic or automated downloading* & 53 & 70.67 & 86 & 57.72 \\
\hline Limits reproduction to personal use & 53 & 70.67 & 114 & 76.51 \\
\hline Refers to fair use or copyright law & 9 & 12.00 & 25 & 16.78 \\
\hline Note $1: \chi^{2}(1, \mathrm{~N}=224)=3.552, * \mathrm{p}=.040<.05$ & \multicolumn{5}{|l}{} \\
\hline
\end{tabular}




\begin{tabular}{|l|c|c|c|c|}
\hline \multicolumn{5}{|c|}{ TABLE 4 } \\
\hline & $\begin{array}{c}\text { Noncommercial } \\
\text { Publisher }\end{array}$ & $\begin{array}{c}\text { Commercial } \\
\text { Publisher }\end{array}$ \\
\cline { 2 - 6 } & $\mathrm{n}=38$ & $\%$ & $\mathrm{n}=186$ & $\%$ \\
\hline Does not address below restrictions & - & - & 6 & 3.23 \\
\hline Forbids systematic or automated downloading** & 35 & 92.11 & 104 & 55.91 \\
\hline Limits reproduction to personal use** & 36 & 94.74 & 131 & 70.43 \\
\hline Refers to fair use or copyright law & 1 & 2.63 & 33 & 17.74 \\
\hline Note 1: $\chi^{2}(1, \mathrm{~N}=224)=17.552, * * \mathrm{p}=.000<.001 ;$ Note $2: \chi^{2}(1, \mathrm{~N}=224)=9.827, * * \mathrm{p}=.001<.001$ \\
\hline
\end{tabular}

sharing"). Examining external sharing over time, we observed a statistically significant drop in the number of licenses prohibiting any external e-distribution ( $44 \%$ to $23 \%$ ). As seen in table 7 , we also found a statistically significant rise in the number of licenses allowing scholarly sharing (39\% to $61 \%)$.

Comparing license types as shown in table 8 , we found two statistically significant findings: Consortia licenses were significantly less likely to prohibit all external e-distribution ( $21 \%$ to $44 \%$ ). Consortia licenses, however, were also significantly more likely to include language prohibiting systematic distribution ( $81 \%$ to $67 \%$ ). We did not find a statistically significant difference between site and consortia licenses' treatment of scholarly sharing despite the noteworthy differences in percentages.

Comparing commercial and noncommercial publisher differences, we found three statistically significant results. As shown in Table 9, commercial licenses were significantly more likely to include a scholarly sharing clause $(0 \%$ to $66 \%$ ). We found no non-commercial licenses that included language allowing scholarly sharing. Also, non-commercial publishers were significantly more likely to prohibit external e-distribution (92\% to $16 \%)$. Commercial publishers were significantly more likely to include language precluding "systematic" e-distribution to external users (84\% to $37 \%$ ).

The above patterns play out in individual publisher data in tables 10 and 11, which show that 100 percent of ACS and OUP licenses prohibited external e-distribution, and no noncommercial publishers include scholarly sharing language. Also of note, OUP and some ELV and SPR licenses were the origin of the observed exemption for submission to patent/regulatory agencies.

Table 11 shows that 100 percent of $\mathrm{T} \& \mathrm{~F}$ and 63 percent of WBL licenses prohibited external e-distribution. In contrast, no WLY, EMR, or SPR licenses contained the prohibition. Almost all of WLY, ELV, SGE, and SPR licenses recognized scholarly sharing. No EMR or T\&F licenses recognized scholarly sharing.

TABLE 5

Downloading Restriction by Noncommercial Publisher

\begin{tabular}{|l|c|c|c|c|c|c|}
\hline \multirow{2}{*}{} & \multicolumn{2}{|c|}{ ACS } & \multicolumn{2}{c|}{ OUP } & \multicolumn{2}{c|}{ CUP } \\
\cline { 2 - 8 } & $\mathrm{n}=16$ & $\%$ & $\mathrm{n}=14$ & $\%$ & $\mathrm{n}=8$ & $\%$ \\
\hline Does not address below restrictions & - & - & - & - & - & - \\
\hline Forbids systematic or automated downloading & 16 & 100.00 & 12 & 85.71 & 7 & 87.50 \\
\hline Limits reproduction to personal use & 16 & 100.00 & 13 & 92.86 & 7 & 87.50 \\
\hline Refers to fair use or copyright law & - & - & 1 & 7.14 & - & - \\
\hline
\end{tabular}




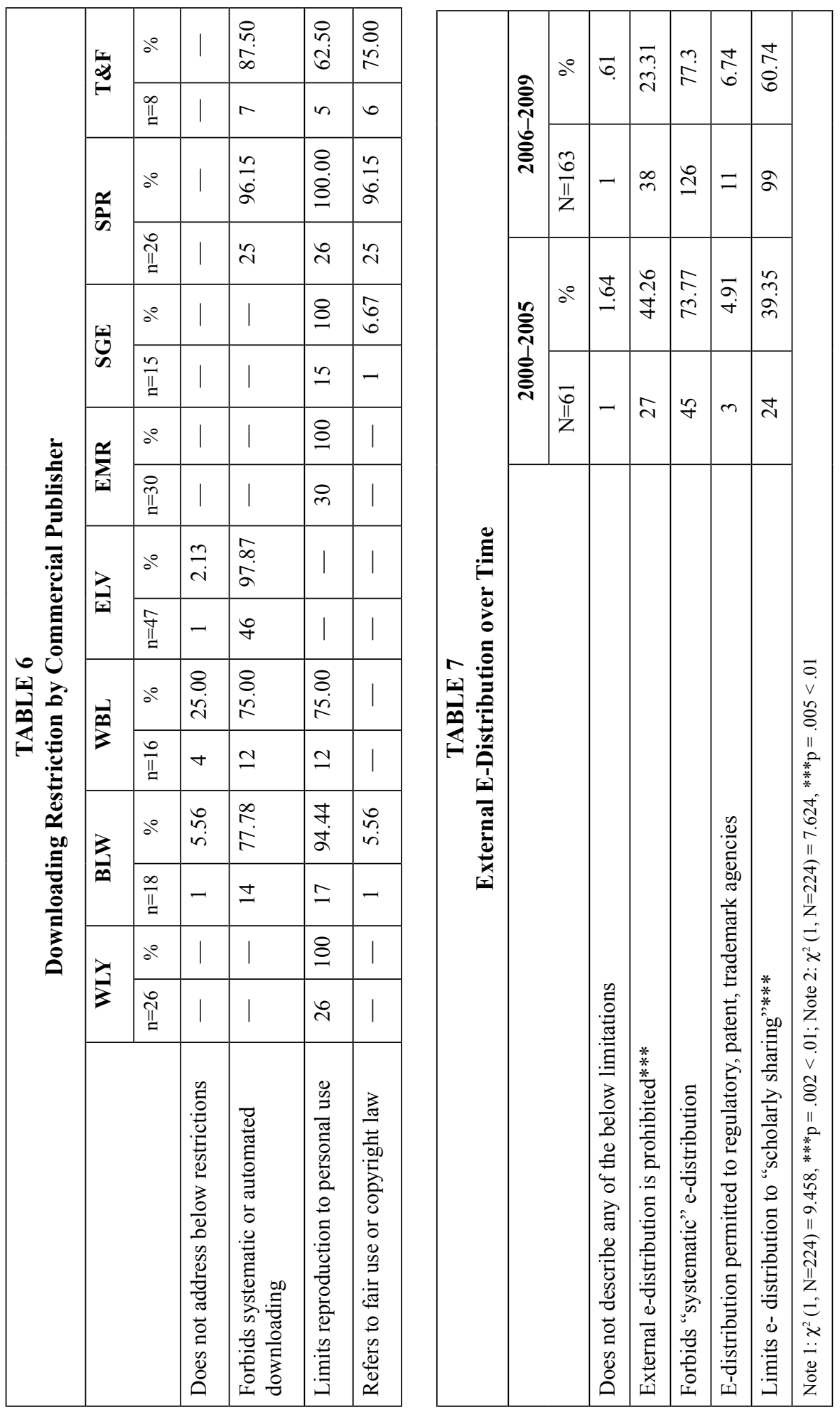




\section{Interlibrary Loan}

Analyzing ILL terms over time in table 12 , we found one statistically significant difference: the number of licenses referring to copyright law or CONTU rose over time. We saw that the number of licenses not addressing ILL remained relatively low over time $(3 \%-5 \%)$, and the number of licenses prohibiting ILL is almost zero.

We had hoped to see a decrease in the print requirement, but we did not. We saw a slight drop in the number of licenses where secure e-transmission was permitted or required $(62 \%$ to $60 \%)$ in table

\begin{tabular}{|l|c|c|c|c|}
\hline \multicolumn{5}{|c|}{ TABLE 8 } \\
External Electronic Distribution by License Type \\
\hline & \multicolumn{2}{|c|}{ Site } & \multicolumn{2}{c|}{ Consortium } \\
\cline { 2 - 6 } & $\mathrm{n}=75$ & $\%$ & $\mathrm{n}=149$ & $\%$ \\
\hline Does not describe any of the below limitations & - & - & 2 & 1.34 \\
\hline External e-distribution is prohibited*** & 34 & 43.55 & 31 & 20.81 \\
\hline Forbids "systematic" e-distribution* & 50 & 66.67 & 121 & 81.21 \\
\hline $\begin{array}{l}\text { E-distribution permitted to regulatory, patent, } \\
\text { trademark agencies }\end{array}$ & 5 & 6.67 & 9 & 6.04 \\
\hline Limits e- distribution to "scholarly sharing" & 31 & 41.33 & 92 & 61.74 \\
\hline Note 1: $\chi^{2}(1, \mathrm{~N}=224)=147.572, * * * \mathrm{p}=.000<.001 ;$ Note $2: \chi^{2}(1, \mathrm{~N}=224)=5.840, * \mathrm{p}=.013<.05$ \\
\hline
\end{tabular}

\section{TABLE 9}

External E-Distribution by Publisher Type

\begin{tabular}{|l|c|c|c|c|}
\hline \multirow{2}{*}{} & \multicolumn{2}{|c|}{$\begin{array}{c}\text { Noncommercial } \\
\text { Publisher }\end{array}$} & \multicolumn{2}{c|}{$\begin{array}{c}\text { Commercial } \\
\text { Publisher }\end{array}$} \\
\cline { 2 - 5 } & $\mathrm{n}=38$ & $\%$ & $\mathrm{n}=186$ & $\%$ \\
\hline Does not describe any of the below limitations & 1 & 2.63 & 1 & .54 \\
\hline External e-distribution is prohibited*** & 35 & 92.11 & 30 & 16.13 \\
\hline Forbids "systematic" e-distribution*** & 14 & 36.84 & 157 & 84.41 \\
\hline $\begin{array}{l}\text { E-distribution permitted to regulatory, patent, } \\
\text { trademark agencies }\end{array}$ & 11 & 28.95 & 3 & 1.61 \\
\hline Limits e-distribution to "scholarly sharing"*** & 0 & - & 123 & 66.49 \\
\hline
\end{tabular}

Note $1: \chi^{2}(1, \mathrm{~N}=224)=88.428, * * * \mathrm{p}=.000<.001 ;$ Note $2: \chi^{2}(1, \mathrm{~N}=224)=39.525, * * * \mathrm{p}=.000<.001$; Note $3: \chi^{2}(1, \mathrm{~N}=224)=56.341, * * * \mathrm{p}=.000<.001$

\begin{tabular}{|l|c|c|c|c|c|c|}
\hline \multicolumn{7}{|c|}{ TABLE 10 } \\
\hline \multirow{2}{*}{ External E-Distribution by Noncommercial Publisher } \\
\hline & \multicolumn{2}{|c|}{ ACS } & \multicolumn{2}{c|}{ OUP } & \multicolumn{2}{c|}{ CUP } \\
\cline { 2 - 9 } & $\mathrm{n}=16$ & $\%$ & $\mathrm{n}=14$ & $\%$ & $\mathrm{n}=8$ & $\%$ \\
\hline $\begin{array}{l}\text { Does not describe any of the below } \\
\text { limitations }\end{array}$ & - & - & - & - & 1 & 12.50 \\
\hline External e-distribution is prohibited & 16 & 100.00 & 14 & 100.00 & 5 & 62.50 \\
\hline Forbids "systematic" e-distribution & - & - & 12 & 85.71 & 2 & 25.00 \\
\hline $\begin{array}{l}\text { E-distribution permitted to regulatory, } \\
\text { patent, trademark agencies }\end{array}$ & - & - & 11 & 78.57 & - & - \\
\hline Limits e-distribution to "scholarly sharing" & - & - & - & - & - & - \\
\hline
\end{tabular}




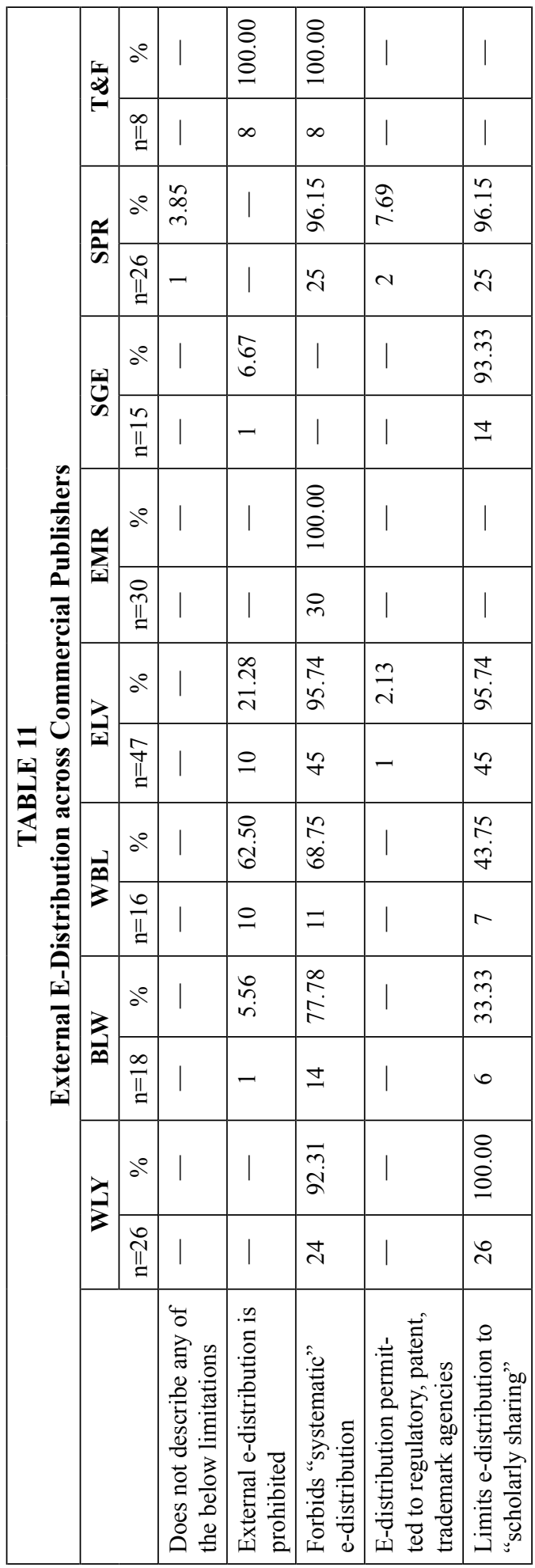

12 , but this decrease is likely due to the very large number of ELV and ACS licenses in the later time period. As explained below, ELV and ACS were less likely to allow secure e-transmission.

Comparing ILL terms between site and consortia licenses in table 13 , we found one statistically significant difference: consortia licenses were significantly more likely to include a print-first requirement ( $71 \%$ to $82 \%)$.

Comparing commercial and noncommercial licenses in table 14, we found two statistically significant differences: Significantly more noncommercial licenses forbid ILL to commercial users/commercial uses $(87 \%$ to $63 \%)$ and significantly more commercial licenses include print requirement ( $84 \%$ to $53 \%$ ).

Tables 15 and 16 show that few SGE or ACS licenses included a print requirement. None of the ACS or ELV licenses we examined listed secure e-transmission as an acceptable means of fulfilling ILL requests. This is noteworthy because the vast majority of publishers' licenses permit e-transmission. On the other hand, no ACS, OUP, WLY or SPR licenses required deletion of an e-reserves file at the end of its use period.

The majority of print requirements appeared as print-first requirements and required printing by the fulfilling library. But four CUP licenses (2005 and 2007) required print delivery, or that the receiving library "make a single paper copy of that [the delivered] document available to an Authorized User of the said other [receiving] library."

\section{Electronic Reserves}

Examining e-reserves license terms over time in table 17, we found three statistically significant dif- 


\begin{tabular}{|l|c|c|c|c|}
\hline \multicolumn{5}{|c|}{ TABLE 12 } \\
\multicolumn{4}{|c|}{} \\
\hline \multicolumn{4}{|c|}{ ILLstrictions over Time } \\
\hline Does not address any of the below limitations & $\mathbf{2 0 0 0}-\mathbf{2 0 0 5}$ & $\mathbf{2 0 0 6}-\mathbf{2 0 0 9}$ \\
\hline ILL prohibited & 3 & 4.92 & 8 & 4.90 \\
\hline Printing part of the ILL process & 1 & 1.64 & 0 & 0 \\
\hline Secure e-transmission technique permitted or required & 46 & 75.4 & 129 & 79.1 \\
\hline No commercial users/uses permitted & 45 & 62.29 & 97 & 59.5 \\
\hline Refers to Copyright Law, Section 108, or CONTU** & 10 & 16.39 & 59 & 36.20 \\
\hline Note 1: $\chi^{2}(1, \mathrm{~N}=224)=8.167, * * \mathrm{p}=.003<.01$ & & & & \\
\hline
\end{tabular}

ferences. First, we saw an increase in the number of licenses that allowed ereserves. Second, we saw a drop in the number of licenses that did not address ereserves at all. Almost no licenses forbade e-reserves. Finally, we found that more new period licenses permitted a hyperlink to articles in their database. We looked for licenses that required a hyperlink and found none. Also important, we examined ILL clauses for references to Copyright Law or CONTU in relation to e-reserves and we found none.

We found one statistically significant difference when we compared consortia and site licenses in table 18 . We found that significantly more consortia licenses (39\% to $23 \%$ ) allow e-reserves without any specific limitations. It is worth pointing out that, because of T\&F (as seen in table 21 below), more site licenses prohibit e-reserves ( $7 \%$ to $0 \%)$. This sample, however, did not contain any T\&F consortia licenses, so we cannot say if T\&F consortia licenses also prohibit e-reserves. The overall number of licenses prohibiting e-reserves is very low.

Analysis by publisher type in table 19 found three statistically significant differences. First, significantly more noncommercial publisher licenses $(68 \%$ to $8 \%$ ) did not explicitly address e-reserves. Second, significantly more commercial licenses $(40 \%$ to $3 \%$ ) allowed e-reserves without any specified limitations. Third, significantly more commercial publisher licenses $(46 \%$ to $13 \%)$ permitted a hyperlink to the article in the database.

Tables 20 and 21 show e-reserves data by individual publisher. First, most T\&F licenses prohibited e-reserves without prior written permission from the pub-

\begin{tabular}{|l|c|c|c|c|}
\hline \multicolumn{5}{|c|}{ TABLE 13 } \\
Comparing ILL by License Type \\
\cline { 2 - 6 } & \multicolumn{2}{|c|}{ Site } & \multicolumn{2}{c|}{ Consortium } \\
\cline { 2 - 6 } & $\mathrm{n}=75$ & $\%$ & $\mathrm{n}=149$ & $\%$ \\
\hline Does not address any of the below limitations & 5 & 6.67 & 6 & 4.03 \\
\hline ILL prohibited & 1 & 1.33 & - & - \\
\hline Printing part of the ILL process * & 53 & 70.67 & 122 & 81.88 \\
\hline Secure e-transmission technique permitted or required & 43 & 57.33 & 92 & 61.74 \\
\hline No commercial users/uses permitted & 54 & 72.00 & 96 & 64.43 \\
\hline Refers to Copyright Law, Section 108, or CONTU & 18 & 24.00 & 51 & 34.23 \\
\hline Note $1: \chi^{2}(1, \mathrm{~N}=216)=4.521,{ }^{*} \mathrm{p}=.027<.05$ & & & & \\
\hline
\end{tabular}




\begin{tabular}{|l|c|c|c|c|}
\hline TABLE 14 \\
ILy Publisher Type \\
\hline & $\begin{array}{c}\text { Noncommercial } \\
\text { Publisher }\end{array}$ & $\begin{array}{c}\text { Commercial } \\
\text { Publisher }\end{array}$ \\
\cline { 2 - 5 } & $\mathrm{n}=38$ & $\%$ & $\mathrm{n}=186$ & $\%$ \\
\hline Does not address any of the below limitations & 2 & 5.26 & 9 & 4.84 \\
\hline ILL prohibited & 1 & 2.63 & - & - \\
\hline Printing part of the ILL process $* * *$ & 20 & 52.63 & 155 & 84.24 \\
\hline Secure e-transmission technique permitted or required & 18 & 47.37 & 117 & 62.90 \\
\hline No commercial users/uses permitted $* *$ & 33 & 86.84 & 117 & 62.90 \\
\hline Refers to Copyright Law, Section 108, or CONTU & 15 & 39.47 & 54 & 29.03 \\
\hline Note 1: $\chi^{2}(1, \mathrm{~N}=224)=18.854, * * * p=.000<.001 ;$ Note $2: \chi^{2}(1, \mathrm{~N}=224)=7.973, * * \mathrm{p}=.003<.01$ \\
\hline
\end{tabular}

lisher. This contrasts greatly with the other publishers in the sample. No noncommercial publisher licenses explicitly prohibited e-reserves. Most ACS and OUP licenses did not address e-reserves at all. Many publisher licenses did not include the requirement to delete e-reserves files at end of use. Most publisher licenses allowed hyperlinks, but EMR, OUP, and SPR licenses did not.

\section{Discussion}

The production and circulation of model license recommended use terms represents one tool to institutionalize best practices to which all library-publisher licenses ought to adhere. Institutional theorists remind us that institutionalization is a process and that, in earlier stages of the process, stakeholders may enact and promote alternative practices. ${ }^{56}$ This paper assesses the degree of institutionalization of model license recommended terms based on their presence or absence in our 224 final licenses. We posit that differences between final license and model license terms indicate less institutionalization, while similarities between final license and model license terms indicate stronger institutionalization of the recommended use terms.

This section first outlines important limitations on the results. It then addresses the research questions by assessing degree of institutionalization over time, variance in institutionalization between site and consortia licenses, and variance in institutionalization between commer-

\begin{tabular}{|l|c|c|c|c|c|c|c|}
\hline \multicolumn{7}{|c|}{ TABLE 15 } \\
ILL across Noncommercial Publishers \\
\hline & \multicolumn{2}{|c|}{ ACS } & \multicolumn{2}{c|}{ OUP } & \multicolumn{2}{c|}{ CUP } \\
\cline { 2 - 9 } & $\mathrm{n}=16$ & $\%$ & $\mathrm{n}=14$ & $\%$ & $\mathrm{n}=8$ & $\%$ \\
\hline Does not address any of the below limitations & - & - & 1 & 7.14 & 1 & 12.50 \\
\hline ILL prohibited & 1 & 6.25 & - & - & - & - \\
\hline Printing part of the ILL process & 1 & 6.25 & 12 & 85.71 & 7 & 87.50 \\
\hline $\begin{array}{l}\text { Secure e-transmission technique permitted or } \\
\text { required }\end{array}$ & - & - & 12 & 85.71 & 6 & 75.00 \\
\hline No commercial users/uses permitted & 15 & 93.75 & 12 & 85.71 & 6 & 75.00 \\
\hline $\begin{array}{l}\text { Refers to Copyright Law, Section 108, or } \\
\text { CONTU }\end{array}$ & 1 & 6.25 & 13 & 92.86 & 1 & 12.50 \\
\hline
\end{tabular}




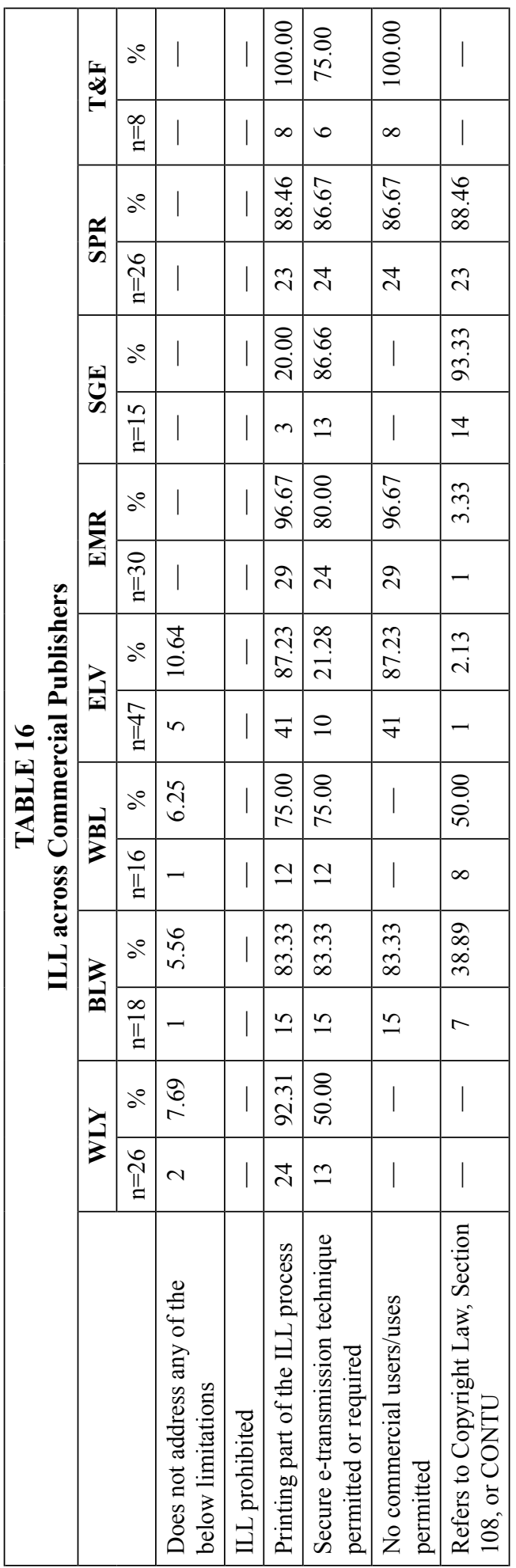

cial and noncommercial licenses. It summarizes whether each publisher's set of licenses shows lower or higher levels of institutionalization in terms of seven model license recommended terms, comparing this study's results with prior studies when possible. It concludes by suggesting future areas of research.

\section{Limitations of Study}

One limitation of our findings is based on social science methodologists' warning that results drawn from one level (example: individual publisher), but aggregated to another level (example: licenses from all commercial publishers), may suffer from if there is high intragroup variation (example: within commercial publishers). ${ }^{57}$ For example, in examining treatment of hyperlinks, this study examined licenses at the publisherlibrary level but made claims about groups of publishers (commercial and noncommercial) and groups of licenses (site and consortia license). If there is a high degree of variation among commercial publishers' treatment of hyperlinks, the group level claim will tend to mask that variation. Our group level difference claims should therefore be held lightly. Because of this limitation, in this section we describe the level of intragroup variation associated with each group level. Readers should also treat our reports of statistical significance with appropriate caution. It is important to remember that a statistically significant finding can still be a spurious finding.

Our ability to compare our findings with previous studies is complicated by differences in each study's sample (that is, which publishers were included) and differences in the nature of each study's data (final license vs. standard license vs. reported terms). Each study's results represents a different, but overlap- 


\begin{tabular}{|c|c|c|c|c|c|c|}
\hline \multicolumn{7}{|c|}{$\begin{array}{l}\text { TABLE } 17 \\
\text { E-Reserves over Time }\end{array}$} \\
\hline & & \multicolumn{2}{|c|}{ 2000-2005 } & \multicolumn{3}{|c|}{ 2006-2009 } \\
\hline & & $\mathrm{N}=61$ & $\%$ & \multicolumn{2}{|c|}{$\mathrm{N}=163$} & $\%$ \\
\hline \multicolumn{2}{|l|}{ Does not address any of the below $*$} & 22 & 36.07 & \multicolumn{2}{|r|}{19} & 11.66 \\
\hline \multicolumn{2}{|l|}{ E-reserves prohibited } & 0 & 0 & \multicolumn{2}{|r|}{5} & 3.07 \\
\hline \multicolumn{2}{|l|}{ Allowed, no specific limitations** } & 12 & 19.67 & \multicolumn{2}{|c|}{63} & 38.65 \\
\hline \multicolumn{2}{|l|}{ Requires deletion of saved files } & 23 & 37.7 & \multicolumn{2}{|c|}{43} & 26.38 \\
\hline \multicolumn{2}{|l|}{ Permits linking*** } & 15 & 24.59 & \multicolumn{2}{|c|}{76} & 46.63 \\
\hline \multicolumn{7}{|c|}{$\begin{array}{l}\text { Note } 1: \chi^{2}(1, \mathrm{~N}=224)=17.686,{ }^{*} \mathrm{p}=.000<.001 ; \text { Note } 2: \chi^{2}(1, \mathrm{~N}=224)=7.178, * * \mathrm{p}=.005<.01 \\
\text { Note } 3: \chi^{2}(1, \mathrm{~N}=224)=8.936,{ }^{* * *} \mathrm{p}=.002<.01\end{array}$} \\
\hline $\begin{array}{r}\text { TABI } \\
\text { E-Reserves by }\end{array}$ & $\begin{array}{l}\text { E } 18 \\
\text { Licen }\end{array}$ & Type & & & & \\
\hline & & & Site & & Conso & rtium \\
\hline & & $\mathrm{n}=7$ & 0 & & $=149$ & $\%$ \\
\hline Does not address any of the below limitations & & 14 & 18. & 67 & 27 & 18.12 \\
\hline E-Reserves not permitted & & 5 & 6.6 & & - & - \\
\hline Allowed, no specific limitations** & & 17 & 22. & & 58 & 38.93 \\
\hline Requires deletion of saved files & & 23 & 32. & & 43 & 28.86 \\
\hline Permits linking & & 31 & 41. & & 60 & 40.27 \\
\hline Note $1: \chi^{2}(1, \mathrm{~N}=224)=5.922, * * \mathrm{p}=.01$ & & & & & & \\
\hline $\begin{array}{r}\text { TABI } \\
\text { E-Reserves by }\end{array}$ & $\begin{array}{l}\text { E } 19 \\
\text { Publis }\end{array}$ & r Typ & & & & \\
\hline & & $\begin{array}{l}\text { ncomr } \\
\text { Publis }\end{array}$ & $\begin{array}{l}\text { nercial } \\
\text { her }\end{array}$ & & $\begin{array}{l}\text { omme } \\
\text { Publis }\end{array}$ & ercial \\
\hline & & $=38$ & $\%$ & $\mathrm{n}=1 \xi$ & 86 & $\%$ \\
\hline Does not address any of the below limitations & & 6 & 68.42 & 15 & & 8.06 \\
\hline E-Reserves prohibited & & - & - & 5 & & 2.69 \\
\hline Allowed, no specific limitations** & & 1 & 2.63 & 74 & & 39.78 \\
\hline Requires deletion of saved files & & 7 & 18.42 & 59 & & 31.72 \\
\hline Permits linking $* * *$ & & 5 & 13.16 & 86 & & $46.24 \%$ \\
\hline $\begin{array}{l}\text { Note } 1: \chi^{2}(1, \mathrm{~N}=224)=76.870,{ }^{*} \mathrm{p}=.000<.001 ; \text { No } \\
\text { Note } 3: \chi^{2}(1, \mathrm{~N}=224)=14.314, * * * \mathrm{p}=.000<.001\end{array}$ & e $2: \chi^{2}$ & $=22$ & $=19.5$ & $\mathrm{k} \cdot \mathrm{p}=$. & $.000<$. & \\
\hline $\begin{array}{r}\text { TABI } \\
\text { E-Reserves across Non } \\
\end{array}$ & $\begin{array}{l}\text { E } 20 \\
\text { omm }\end{array}$ & cial Pr & blishe & & & \\
\hline & & & $\mathbf{O}$ & UP & & CUP \\
\hline & $\mathrm{n}=16$ & $\%$ & $\mathrm{n}=14$ & $\%$ & $\mathrm{n}=8$ & $\%$ \\
\hline Does not address any of the below limitations & 16 & 00.00 & 13 & 92.86 & 1 & 12.50 \\
\hline E-Reserves prohibited & - & - & - & - & - & - \\
\hline Allowed, no specific limitations & - & - & 1 & 7.14 & - & - \\
\hline Requires deletion of saved files & - & - & - & - & 7 & 87.50 \\
\hline Permits linking & 4 & 25.00 & - & - & 1 & 12.50 \\
\hline
\end{tabular}




\begin{tabular}{|c|c|c|c|c|c|c|c|}
\hline & \multirow{2}{*}{$\stackrel{5}{*}$} & $\partial^{\circ}$ & $\mid$ & $\begin{array}{l}8 \\
\text { லூ }\end{array}$ & $\begin{array}{l}8 \\
\ddot{i}\end{array}$ & 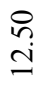 & $\begin{array}{l}\text { ก } \\
\text { ชิ }\end{array}$ \\
\hline & & $\stackrel{\infty}{=}$ & | & in & $\sim$ & - & $n$ \\
\hline & $\simeq$ & $\partial^{0}$ & $\begin{array}{l}\tilde{\sigma} \\
\dot{m}\end{array}$ & $\mid$ & 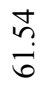 & 1 & $\mid$ \\
\hline & $\bar{n}$ & $\stackrel{\mathbb{N}}{\|}$ & $a$ & $\mid$ & $\stackrel{0}{0}$ & $\mid$ & $\mid$ \\
\hline & & $\partial^{0}$ & | & | & $\begin{array}{l}\hat{b} \\
\dot{0}\end{array}$ & $\begin{array}{l}\hat{\sigma} \\
\dot{0}\end{array}$ & $\begin{array}{l}8 \\
\stackrel{0}{0}\end{array}$ \\
\hline & $\varpi$ & $\stackrel{n}{\pi}$ & | & 1 & $\stackrel{m}{2}$ & - & $m$ \\
\hline & $\mathscr{\simeq}$ & $\partial^{0}$ & $\mid$ & $\mid$ & $\mid$ & $\stackrel{8}{\circ}$ & $\mid$ \\
\hline 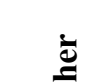 & 兵 & 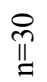 & $\mid$ & $\mid$ & $\mid$ & $\stackrel{\nabla}{\sim}$ & $\mid$ \\
\hline ב) & $>$ & $\partial^{\circ}$ & 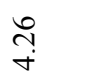 & $\mid$ & 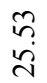 & $\frac{n}{9}$ & $\begin{array}{l}\vec{\not} \\
\infty\end{array}$ \\
\hline $\bar{\sim}$ & $\bar{x}$ & $\stackrel{f}{\sharp}$ & $\sim$ & $\mid$ & $\simeq$ & $a$ & \& \\
\hline$\sum_{0}$ & $\overline{0}$ & $\partial^{0}$ & กิ & $\mid$ & $\begin{array}{l}8 \\
\ddot{i}\end{array}$ & $\begin{array}{l}n \\
\infty \\
\infty\end{array}$ & $\begin{array}{l}8 \\
\stackrel{0}{\circ}\end{array}$ \\
\hline & 3 & $\stackrel{0}{\Perp}$ & - & $\mid$ & $\nabla$ & $=$ & $\infty$ \\
\hline $\begin{array}{l}\overline{0} \\
\overline{0} \\
\simeq\end{array}$ & 3 & $\partial^{0}$ & $\begin{array}{l}\text { in } \\
i n\end{array}$ & $\mid$ & $\begin{array}{l}\hat{6} \\
6\end{array}$ & 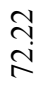 & $\hat{m}$ \\
\hline & $\bar{n}$ & $\prod_{=}^{\infty}$ & - & $\mid$ & $m$ & 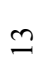 & 0 \\
\hline & 3 & $\partial^{0}$ & $\frac{6}{3}$ & $\mid$ & 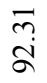 & $\mid$ & $\begin{array}{l}\bar{\kappa} \\
\text { à }\end{array}$ \\
\hline & $k$ & 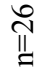 & $\sim$ & $\mid$ & $\stackrel{\searrow}{\sim}$ & 1 & $\stackrel{ \pm}{\sim}$ \\
\hline & & & 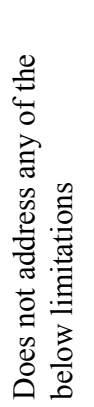 & 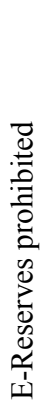 & 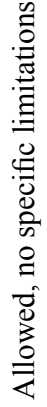 & 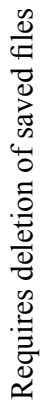 & 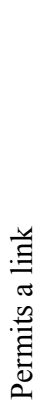 \\
\hline
\end{tabular}

ping, look at licensing practice. That being said, this paper's data overlap with prior studies in terms of some publishers and time period. Given the known differences in samples, concordance in findings across studies is important evidence of trends. Lack of concordance across study findings points to unexplained variation and fruitful areas for future investigation.

Another limitation is that we did not have the resources to distinguish what level of service each license addressed. Our analysis groups together all licenses from a given publisher. If e-journal packages (like cable TV) contain different levels of service and different tiers of content, we did not measure that variance. It could be that "deluxe" licenses came with more liberal use rights. Importantly, we did not observe different terms of use for different subject areas of content (for instance, some use rights for science journals, other rights for humanities journals). As noted earlier, e-book content did have separate terms of use, but we did not include ebook terms of use in our analysis.

\section{Q1: Did model license recommended terms} become more institutionalized over time?

We found several statistically significant changes suggesting that some use terms have become more institutionalized over time. First, the number of licenses including scholarly sharing clauses had increased in a statistically significant manner (39\% to $61 \%$ ). This rise suggests a growing institutionalization of model license terms recommending scholarly sharing. Second, we found a statistically significant increase in the number of ILL terms referring to copyright law or CONTU; however, the overall percent of licenses doing so is still low (36\%). This suggests low, but growing, institutionalization of those model license terms.

We found three statistically significant changes with regard to e-reserves: an increase in the number of licenses that permitted e-reserves with no specific limitation described (20\% to $39 \%$ ), a decrease in the number of licenses that did 
not address (were silent) on e-reserves (a drop of $36 \%$ to $12 \%$ ), and an increase in the number of licenses permitted deeplinking hyperlinks (25\% to $47 \%$ ). These results suggest that model license language recommending recognition of e-reserves has become more institutionalized. It also suggests low, but growing, institutionalization of model license language recommending hyperlinks.

\section{Q2: Were model license use terms more institutionalized in consortia licenses?}

One might assume that consortia licenses contain better use terms because of greater negotiating power of consortia and the possibility that consortia might have more license negotiation resources such as experienced staff familiar with model license recommendations. Given this assumption, model license recommendations ought to be more institutionalized in consortia licenses.

Analysis shows that, in two out of three cases, consortia licenses were significantly more likely to contain use term language promoted by model licenses. ${ }^{58}$ First, consortia licenses were significantly less likely to prohibit all external e-distribution. But tables 10 and 11 show a good deal of variation in an individual publisher's prohibition of e-distribution, illustrating that the group level claim does not hold true for all publishers. For example, table 10 suggests that noncommercial licenses prohibit e-distribution in both site licenses and consortia licenses.

Second, we found that consortia licenses were more likely to permit e-reserves without specific limitations. However, publisher-level data in tables 20 and 21 show high variation, illustrating that the finding does not hold up across all publishers. Few noncommercial consortia licenses, and no EMR consortia licenses, permit e-reserves without specific limitations.

We also found that consortia licenses were more likely to include the printfirst requirement for ILL, a use term that model licenses recommend avoiding. One would have hoped that consortia would be more successful in avoiding print requirements, but our data show this was not the case. That being said, examining publisher- level data shows that certain publishers (ACS, SGE) were less likely to employ print requirements regardless of type of license.

These findings suggest that, while model license terms for external e-distribution and e-reserves were more institutionalized in consortia licenses, important publisher-level differences exist. Further, recommendations to avoid print requirements were not more institutionalized in consortia licenses. Previous licensing research has not compared site and consortia licenses, so we cannot compare our results to other results.

\section{Q3: How did institutionalization of model license use terms vary between commercial and noncommercial publishers?}

Overall, our findings suggest that model license use terms are less institutionalized in noncommercial licenses: Our noncommercial licenses were less likely to include suggested use terms. Our results about commercial and noncommercial publisher differences suffer from the same intragroup variation limitation as the above site/consortium data, so this section explicitly describes the level of intragroup variation associated with each finding. ${ }^{59}$

We found statistically significant differences between commercial and noncommercial publisher licenses in all four use term areas. In reviewing the results, we compare our findings with Davis and Feather's earlier study that contained mostly noncommercial licenses (including ACS, OUP, and CUP). ${ }^{60}$

We found that noncommercial licenses were less likely to include the model license recommended scholarly sharing terms ( $0 \%$ to $66 \%$ ). Davis and Feather's analysis of 2006 of mostly noncommercial licenses found that 28.6 percent of their licenses permitted scholarly sharing, while 48.6 percent prohibited it. But they did not distinguish between the commercial and 
noncommercial results. It could be that most of the Davis and Feather licenses that permitted scholarly sharing were commercial. Our data in tables 10 and 11 also show that two commercial publishers (T\&F and EMR) did not recognize scholarly sharing. This highlights that certain commercial publishers also do not include the model license suggested terms.

We also found that noncommercial licenses were more likely to prohibit ILL to commercial users/uses. Unfortunately, prior studies did not report on this aspect of ILL, so we cannot compare our results. Publisher level ILL data in tables 15 and 16 show low variability among noncommercial publishers - most did not allow commercial users/uses of ILL. Commercial publisher data show more variation; WLY, WBL and SGE licenses did not forbid ILL to commercial users/ uses, but most others did.

Table 21 shows that neither commercial nor non commercial licenses prohibited e-reserves. Most commercial licenses addressed e-reserves, but our noncommercial licenses were more varied. Comparing our results with previous studies, Farb analyzed a different set of noncommercial publisher model licenses and found they did address e-reserves. ${ }^{61}$ This variation in our noncommercial data and the variation across studies suggest low levels of institutionalization of model license ILL recommendations among noncommercial publishers. Noncommercial licenses were also less likely to permit a hyperlink for e-reserves (13\% to $46 \%$ ). Unfortunately, prior studies did not report on hyperlinks, so we cannot compare our results.

On a positive note, noncommercial licenses were less likely to include a print requirement for ILL ( $53 \%$ to $84 \%$ ); however, the overall percent of licenses requiring print is still high. Overall, the results suggest that model license recommendations to avoid print requirements have not become strongly institutionalized in either commercial or noncommercial licenses. Further, our results agree with prior studies showing that only around half $(46 \%)$ of noncommercial publishers permit secure e-transmission for ILL (thereby not requiring printing to mail or fax ILL requests). In our analysis, just under half $(47 \%)$ of the noncommercial licenses permitted secure e-transmission.

As a whole, our findings suggest more limited institutionalization of model license use terms in noncommercial licenses. However, high within-group variance limits these findings. Further, differences in data reporting among studies limit cross-study comparisons.

\section{Q4: How did institutionalization of model license terms vary by publisher?}

In answering the question of which publishers' licenses were more likely to contain model license recommendations, we first had to analyze which model license recommendations were the most institutionalized. We begin this section by describing our analysis for the latter question. Then we rank publishers in terms of the degree to which their licenses institutionalized model license recommendations.

\section{4a. Which recommended use terms are more institutionalized?}

The analysis in table 22 depicts which use terms are more institutionalized and which are less institutionalized. It groups publishers' licenses in four sets indicating what percent of each publisher's licenses comported with the recommended use term. The groupings include Low ( $0 \%-$ $25 \%$ of licenses), Medium-Low $(26 \%-50 \%$ of licenses), Medium (51\%-75\% of licenses), and High (76\%-100\% of licenses). Looking across the columns, one can see where each publisher sits in terms of level of institutionalization of a given license term. The final column compares the column-based institutionalization level ratings with the overall percentage of licenses that contain the recommended use term.

This section continues by discussing each area of high and then low institutionalization. 
Use Terms with Higher Institutionalization The analysis in Table 22 shows one instance where the majority (six or more) of publishers ranked as strongly institutionalized for a model license recommendation (E-reserves: Do not require deletion of file). For another recommended use term, secure e-transmission systems for ILL, the majority of publishers ranked medium or strong for institutionalization.
Model licenses also recommend that licenses allow ILL. Only one license out of our 224 licenses forbade ILL. This strongly suggests that some model license recommended ILL terms have become much more institutionalized. It also shows an improved picture from Davis \& Feather's and Farb's earlier analyses where $25.7 \%$ and $15 \%$ respectively prohibited ILL. ${ }^{62}$

\begin{tabular}{|c|c|c|c|c|c|}
\hline \multicolumn{6}{|c|}{$\begin{array}{c}\text { TABLE } 22 \\
\begin{array}{c}\text { Comparison of Publishers by Model License Recommendations } \\
\text { and by Typical Publisher Use Terms }\end{array}\end{array}$} \\
\hline & \multicolumn{4}{|c|}{$\begin{array}{l}\text { Percent of Each Publisher's } \\
\text { Licenses that Contain } \\
\text { the Model License } \\
\text { Recommended Use Term }\end{array}$} & \\
\hline $\begin{array}{l}\text { Model License } \\
\text { Recommended } \\
\text { Use Term }\end{array}$ & $\begin{array}{l}0 \%- \\
25 \%\end{array}$ & $\begin{array}{c}26 \%- \\
50 \%\end{array}$ & $\begin{array}{l}51 \%- \\
75 \%\end{array}$ & $\begin{array}{l}76 \%- \\
100 \%\end{array}$ & Summary \\
\hline $\begin{array}{l}\text { Mention fair use } \\
\text { in relation to } \\
\text { downloading }\end{array}$ & $\begin{array}{l}\text { ACS, } \\
\text { OUP, } \\
\text { CUP, } \\
\text { WLY, } \\
\text { BLW, } \\
\text { WBL, } \\
\text { ELV, } \\
\text { EMR, } \\
\text { SGE }\end{array}$ & & $\mathrm{T} \& \mathrm{~F}$ & SPR & $\begin{array}{l}\text { Most licenses do not mention fair } \\
\text { use in relation to downloading } \\
(17 \%) \text {. This suggests low insti- } \\
\text { tutionalization of model license } \\
\text { recommendations. }\end{array}$ \\
\hline $\begin{array}{l}\text { Recognize } \\
\text { scholarly sharing }\end{array}$ & $\begin{array}{l}\text { ACS, } \\
\text { OUP, } \\
\text { CUP, } \\
\text { EMR, } \\
\text { T\&F }\end{array}$ & $\begin{array}{l}\text { BLW, } \\
\text { WBL }\end{array}$ & & $\begin{array}{l}\text { WLY, } \\
\text { ELV, } \\
\text { SGE, } \\
\text { SPR }\end{array}$ & $\begin{array}{l}\text { While the majority of licenses } \\
(55 \%) \text { acknowledge scholarly shar- } \\
\text { ing, suggesting higher institutional- } \\
\text { ization of model license recommen- } \\
\text { dations, seven out of } 11 \text { publishers } \\
\text { show lower levels of institutional- } \\
\text { ization. The high number of WLY, } \\
\text { ELV, SGE, and SPR licenses in the } \\
\text { sample skew the results. }\end{array}$ \\
\hline $\begin{array}{l}\text { No print } \\
\text { requirement in } \\
\text { ILL* }\end{array}$ & $\begin{array}{l}\text { OUP, } \\
\text { CUP, } \\
\text { WLY, } \\
\text { BLW, } \\
\text { WBL, } \\
\text { ELV, } \\
\text { EMR, } \\
\text { SPR, } \\
\text { T\&F }\end{array}$ & & & $\begin{array}{l}\text { ACS } \\
\text { SGE }\end{array}$ & $\begin{array}{l}\text { Most licenses include a print re- } \\
\text { quirement }(79 \%) \text {. This suggests low } \\
\text { institutionalization of model license } \\
\text { recommendation to avoid printing } \\
\text { requirements. }\end{array}$ \\
\hline
\end{tabular}




\begin{tabular}{|c|c|c|c|c|c|}
\hline \multicolumn{6}{|c|}{$\begin{array}{c}\text { TABLE } 22 \\
\begin{array}{c}\text { Comparison of Publishers by Model License Recommendations } \\
\text { and by Typical Publisher Use Terms }\end{array}\end{array}$} \\
\hline & \multicolumn{4}{|c|}{$\begin{array}{l}\text { Percent of Each Publisher's } \\
\text { Licenses that Contain } \\
\text { the Model License } \\
\text { Recommended Use Term }\end{array}$} & \multirow[b]{2}{*}{ Summary } \\
\hline $\begin{array}{l}\text { Model License } \\
\text { Recommended } \\
\text { Use Term }\end{array}$ & $\begin{array}{l}0 \%- \\
25 \%\end{array}$ & $\begin{array}{c}26 \%- \\
50 \%\end{array}$ & $\begin{array}{c}51 \%- \\
75 \%\end{array}$ & $\begin{array}{l}76 \%- \\
100 \%\end{array}$ & \\
\hline $\begin{array}{l}\text { Secure } \\
\text { e-transmission } \\
\text { permitted or } \\
\text { required for ILL }\end{array}$ & $\begin{array}{l}\text { ACS, } \\
\text { ELV }\end{array}$ & WLY & $\begin{array}{l}\text { CUP, } \\
\text { WBL, } \\
\text { T\&F }\end{array}$ & $\begin{array}{l}\text { OUP, } \\
\text { BLW, } \\
\text { EMR, } \\
\text { SGE, } \\
\text { SPR }\end{array}$ & $\begin{array}{l}\text { Most licenses permit or require } \\
\text { secure e-transmission for ILL } \\
(60 \%) \text { and eight of eleven publisher } \\
\text { licenses tend to include this recom- } \\
\text { mendation. This suggests higher } \\
\text { institutionalization of the recom- } \\
\text { mendation. }\end{array}$ \\
\hline $\begin{array}{l}\text { Allow ILL for } \\
\text { commercial } \\
\text { users* }\end{array}$ & $\begin{array}{l}\text { ACS, } \\
\text { OUP, } \\
\text { CUP, } \\
\text { BLW, } \\
\text { ELV, } \\
\text { EMR, } \\
\text { SPR, } \\
\text { T\&F }\end{array}$ & & & $\begin{array}{l}\text { WLY, } \\
\text { WBL, } \\
\text { SGE }\end{array}$ & $\begin{array}{l}\text { Most licenses do not permit ILL to } \\
\text { commercial users }(64 \%) \text { and eight } \\
\text { publishers' licenses tend to not } \\
\text { allow it. This suggests low institu- } \\
\text { tionalization of this model license } \\
\text { recommendation. }\end{array}$ \\
\hline $\begin{array}{l}\text { Permit } \\
\text { hyperlinks for } \\
\text { e-reserves }\end{array}$ & $\begin{array}{l}\text { ACS, } \\
\text { OUP, } \\
\text { CUP, } \\
\text { EMR, } \\
\text { SGE, } \\
\text { SPR }\end{array}$ & $\begin{array}{l}\text { BLW, } \\
\text { WBL }\end{array}$ & $T \& F$ & $\begin{array}{l}\text { WLY, } \\
\text { ELV }\end{array}$ & $\begin{array}{l}\text { Many licenses still do not explicitly } \\
\text { permit hyperlinks }(46.63 \%) \text { and } \\
\text { eight publishers' licenses tend not to } \\
\text { include the recommended use term. } \\
\text { Data, however, show a statistically } \\
\text { significant increase in licenses' use } \\
\text { of the term over time. Data could } \\
\text { be skewed by the high number of } \\
\text { recent period ELV licenses. The } \\
\text { combined data do not present a very } \\
\text { convincing case for institutionaliza- } \\
\text { tion of this model license recom- } \\
\text { mended use term. }\end{array}$ \\
\hline $\begin{array}{l}\text { Do not require } \\
\text { deletion of e- } \\
\text { reserves file after } \\
\text { use* }\end{array}$ & $\begin{array}{l}\text { CUP, } \\
\text { BLW, } \\
\text { EMR }\end{array}$ & WBL & & $\begin{array}{l}\text { ACS, } \\
\text { OUP, } \\
\text { WLY, } \\
\text { ELV, } \\
\text { SGE, } \\
\text { SPR, } \\
\text { T\&F }\end{array}$ & $\begin{array}{l}\text { Most licenses do not include the } \\
\text { requirement to delete e-reserves } \\
\text { file after use ( } 74 \% \text { in } 2006-2009 \\
\text { period). Seven out of } 11 \text { publishers } \\
\text { tend to allow file retention. This } \\
\text { suggests strong institutionalization } \\
\text { of this practice despite the fact that } \\
\text { model licenses do not specifically } \\
\text { recommend it. }\end{array}$ \\
\hline
\end{tabular}


Model licenses also recommend that licenses explicitly permit e-reserves. On a good note, our study data show no final licenses in this study prohibited e-reserves. This suggests strong institutionalization of e-reserves as an allowable service. Further, most of our licenses explicitly recognized e-reserves (rather than remaining silent). Previous work showed that many mid-2000 licenses were still silent on e-reserves. Our results show that most 2006-2009 licenses (over 87\%) explicitly recognized e-reserves.

Our analysis shows high institutionalization of e-reserves use terms that do not require deletion of electronic files upon completion of use (typically the end of the semester). Only CUP, BLK, WBL and EMR regularly required deletion of files. It is not clear why this is the case. Because libraries must subscribe to a publisher's platform to access and legally reuse materials, arguably allowing reuse does not impact publishers' revenues. Also of note is that the lack of a requirement to delete after completion of use, which arguably saves libraries work, was not included in the model licenses we examined for this study. Given that our data show that some publishers routinely require deletion, and that the requirement is burdensome to libraries, model licenses might consider adding recommended text in this area.

In terms of scholarly sharing, our data can suggest only modest institutionalization. Despite this, our results show a rosier picture than earlier studies that reported lower recognition of scholarly sharing. For example, Davis and Feather's study found that $28.6 \%$ of their licenses permitted scholarly sharing and only $33 \%$ of Farb's licenses permitted scholarly sharing. In comparison, $66 \%$ of our $2006-$ 2009 licenses recognized scholarly sharing. ${ }^{63}$ Looking at specific publishers, Farb found that BLW, ELV and WLY standard licenses did not include scholarly sharing rights. As seen in Table 11, all of our WLY final licenses and over 95\% of our ELV licenses included scholarly sharing. ${ }^{64}$ Only some of our BLW and WBL licenses did so (under $50 \%$ ). This suggests that either ELV changed their standard license to recognize scholarly sharing, or that ELV was more willing to negotiate recognition of scholarly sharing in final licenses.

Finally, while the majority $(60 \%)$ of our licenses permitted use of secure etransmission, and Table 22 suggests this recommendation is becoming institutionalized, a stubborn $40 \%$ of our licenses did not include this recommended use term; and, that percentage did not change significantly during the study period. This suggests a stalled process of institutionalization. It is important to recall that during 2000-2009, full text database content became discoverable through tools like Google Scholar. This likely increased demand for articles by users at non-subscribing institutions. Publishers seeking to exploit this market would have motivation to keep ILL costly via the print-first requirement and through prohibiting ILL to commercial users.

Use Terms with Lower Institutionalization Table 22 shows several instances where the majority (six or more) publishers ranked low for institutionalization. The analysis suggests that the following use term recommendations have weak institutionalization in this sample of licenses: not including print requirements for ILL, permitting hyperlinks, permitting ILL for commercial users/uses, and fair use clauses in relation to downloading.

Our results in Table 22 show that final licenses have not institutionalized model license recommendations to avoid print requirements. In our data set, $79 \%$ of licenses, and the majority of publisher license sets, included a print requirement. It is difficult to compare our results with earlier studies due to differences in data coding. Davis and Feather however, reported that $46 \%$ of mostly non-commercial 2006 licenses did not allow e-transmission for ILLThis would thereby requiring print. ${ }^{65}$ Unfortunately, they did not report how 
many allowed e-transmission but required printing as part of the etransmission process.

Table 22 also suggests weak institutionalization of model license hyperlink recommendations. Some publishers' final licenses routinely allow hyperlinks (WLY, ELV), some never do (EMR, SPR, OUP), and some publishers vary (ACS, WBL, SGE). Publishers may avoid hyperlink permissions to limit the convenience of e-reserves. Less convenience might increase demand for paper course packs, which might generate rights permissions fees, or textbooks. Prior studies did not examine hyper linking license text, so we cannot compare our results. Finally, our licenses showed weak institutionalization of ILL for commercial users/uses and weak fair use clauses in relation to downloading.

\section{4b. Which Publishers Licenses Are More Likely to Contain Model License Terms?}

Table 23 develops an overall ranking of institutionalization of model license recommended terms for each publisher. A higher score represents greater institutionalization of recommended terms. The table takes the percent categories from table 22 and assigns a score of 1 to publishers with a "Low" ranking, a score of 4 to publishers with a "High" ranking, and so forth.

As shown in table 23, SGE licenses receive the highest overall ranking (22, or $79 \%)$, suggesting that SGE has the most institutionalized model license recommended terms. WLY is next, followed closely by SPR with a score of 19, or 68 percent. Most publishers scored lower, at 16 or fewer possible points with a low score of 9 by CUP. It is important to recall that these scores are dependent on the model license terms chosen for analysis. A different set of license 
terms could result in different publisher rankings.

These data are summarized in table 24, which lists the publishers in order from those with the most institutionalized licenses to the least institutionalized licenses.

\section{Future Research}

The study's findings suggest several areas for further research. First, because our conclusions are limited by the fact that our sample drew only from licenses signed by large public academic libraries, further research controlling for different types of universities and libraries would provide useful comparisons.

Further research is needed to explain the lack of institutionalization shown in some of our results. Studies that compared licenses from high and low resource libraries could shed light on the role of resources in institutionalization. Future research could also examine the impact of license training on institutionalization of model license terms. Similarly, future work might also examine what makes some publishers less likely to adopt recommended license language.

Another question raised by our analysis is the relationship between pricing and use rights. While we have no pricing data for the sample licenses, it is widely acknowledged that commercial publishers charge higher prices than noncommercial publishers. ${ }^{66}$ Commercial publishers might seek to soften the blow of those price hikes by being more accommodating with use terms in their standard licenses. The authors hope to explore the link between pricing and use rights further.

Our results also suggest some intriguing differences between site and consortia licenses, and further comparison of site and consortia licenses could be fruitful; further, inclusion of national-level licenses from other nations would be particularly insightful.

\section{Implications and Conclusion}

The data produced in this study track how use rights for journal content have changed from 2000 to 2009 in a sample of licenses between large state universities and major academic publishers. Knowing what licenses say is an important element in understanding how the practice of licensing has changed access to and use of scholarly information published

\begin{tabular}{|l|c|c|}
\hline \multicolumn{3}{|c|}{ TABLE 24 } \\
\hline Publisher Overall Rankings \\
\hline & $\begin{array}{c}\text { Level of Institutionalization } \\
\text { of Model License } \\
\text { Recommended Terms } \\
\text { in Licenses (Raw Score from } \\
\text { High to Low) }\end{array}$ & $\begin{array}{c}\text { Raw Score/28 } \\
\text { possible points } \\
\text { \% percent rank }\end{array}$ \\
\hline (SGE) Sage & 22 & 79 \\
\hline (WLY) Wiley & 20 & 71 \\
\hline (SPR)Springer & 19 & 68 \\
\hline $\begin{array}{l}\text { (ELV) Elsevier; (T\&F) Taylor and } \\
\text { Francis }\end{array}$ & 16 & 57 \\
\hline (WBL) Wiley-Blackwell & 15 & 54 \\
\hline (BLW) Blackwell & 12 & 42 \\
\hline $\begin{array}{l}\text { (ACS) American Chemical Society; } \\
\text { (OUP) Oxford University Press; }\end{array}$ & 13 & 46 \\
\hline (EMR) Emerald & 10 & 36 \\
\hline (CUP) Cambridge University Press & 9 & 32 \\
\hline
\end{tabular}


in journals. By pointing out areas where model license recommendations have not become institutionalized, we hope our analysis will further licensing activism and licensing education.

We hope that our analysis of current practices in licensing can be used by both publishers and libraries to normalize use terms and to reduce the burden of negotiations by providing data about what peers are doing. This may be particularly important for smaller publishers or libraries that may lack in-house staff to focus on changes in licensing practice. Data from this study should also inform efforts to develop alternative exchange governance mechanisms by pointing out what license terms are currently commonly used.

One other finding from this study that merits further discussion is conflict between some common license use terms and day-to-day end-user practice. Our data show that, in some instances, publishers use licenses to forbid activities that many end users would consider morally unproblematic. For example, our data show that ACS, OUP, and T\&F licenses did not permit any external edistribution, seemingly even for scholarly sharing. This suggests that a graduate student who e-mails a copy of an article to one colleague at a different institution violates the license. This, combined with recent events surrounding the Aaron Swartz JSTOR hacking case and tragic suicide, raise uncomfortable questions about the implications of license breaches. ${ }^{67}$ Typically, end-user license breach problems are managed through university administrative processes and technological fixes. ${ }^{68}$ But the Swartz case involved federal prosecution. ${ }^{69}$ While comparing the Swartz case to end users' casual e-mail distribution is extreme, the Swartz case shows that, in some cases, end users could be held criminally liable for damages resulting from a license breach. This possibility, even remote, makes it important to pay attention to license terms that conflict with typical user behaviors.

The study results also highlight how some publishers continue to include license terms that require unfortunate uses of library time and resources. For example, use terms requiring printing and rescanning of e-journal articles to fulfill an ILL request and use terms that require deletion of regularly used e-reserves increase library staff costs without any value to end users of the library. In an era of shrinking budgets and increased calls for accountability, many end users, taxpayers, and their elected representatives would likely be shocked by these use terms. It may be time to shed greater light on these practices to further shift licensing practice. 


\section{Appendix A: Codebook}

Please contact first author for a complete copy of the codebook.

Does this license in any way limit downloading/saving of licensed content by authorized users? (Mark all that apply.)

- Does not address below listed restrictions on downloading or saving.

- Forbids systematic or automated downloading/saving, including that done by robots or intelligent agents.

- Limits reproduction to personal use only (includes research, education, personal need, etc.).

- Refers to fair use or copyright law limitation

Does this license in any way limit the electronic distribution of works by authorized users to_nonauthorized users? (Mark all that apply.)

- Does not describe any of the below limitations on external e-distribution.

- External e-distribution is prohibited.

- Forbids "systematic" e-distribution to external users.

- Limits e-distribution to "scholarly sharing" or similar term (assumes it is for the nonauthorized recipients' personal/research use only).

Does this license allow works to be used in electronic reserves for credit courses? (Mark all that apply.)

- Does not address any of the below listed limitations on e-reserves.

- E-reserves prohibited.

- Allowed, and no specific limitations are described.

- Permits a link to the article in the database.

- $\quad$ Refers to fair use, Copyright Act, or CONFU guidelines.

Does this license allow use of the work in interlibrary loan? (Mark all that apply.)

- Does not address any of the below listed limitations on ILL.

- ILL prohibited.

- Printing is mentioned as part of the ILL process - such as before sending via fax, e-transmission, mail-or before giving document to patron.

- "Secure e-transmission" technique listed as an option (or required) for transmission.

- No sending to commercial users/no commercial uses permitted, or file must only be used for purposes of research or private study.

- $\quad$ Refers to Copyright Law, Section 108, or CONTU.

\section{Notes}

1. Leslie E. Harris, Licensing Digital Content, 2nd ed. (Chicago: ALA, 2009).

2. Harris, Licensing Digital Content; "Liblicense: Licensing Digital Information, a Resource for Librarians," available online at www.library.yale.edu/ llicense/index.shtml [accessed December 2011].

3. Interested readers should examine the SERU project (http://www.niso.org/workrooms/ seru). Moreover, publishers "sell" some electronic resources such as e-books to libraries. This paper does not include licenses for these types of exchanges.

4. Council on Library and Information Resources (CLIR), Digital Library Federation (DLF), "Liblicense Model License Agreement \& Commentary," available online at www.library.yale. edu/ llicense/standlicagree.1st.html [accessed May 2011].

5. ICOLC, "Statement of Current Perspective and Preferred Practices for the Selection and Purchase of Electronic Information: Update No. 1: New Developments In E-Journal Licensing," 
available online at www.library.yale.edu/consortia/2001currentpractices.htm [accessed May 2011].

6. Committee on Institutional Cooperation (CIC), "CIC Standardized Agreement Language," available online at www.cic.net/home/projects/Library/Licensing/StandAgreementLang.aspx [accessed May 2011].

7. International Association of Scientific Technical and Medical Publishers (STM), "STM Statement on Document Delivery," available online at www.stm-assoc.org/industry-news/stmstatement-on-document-delivery/ [accessed 31 May 2011].

8. Richard W. Scott, Institutions and Organizations: Ideas and Interests (Los Angeles: Sage Publications, 2007).

9. Kristin R. Eschenfelder, Anuj C. Desai, and Greg Downey, "The Pre-Internet Downloading Controversy: The Evolution of Use Rights for Licensed Electronic Resources," Information Society 27, no. 2 (2011): 69-91.

10. Ted C. Bergstrom, Paul Courant, and R.Preston McAfee, "Big Deal Contract Project," available online at www.econ.ucsb.edu/ tedb/Journals/BundleContracts.html [accessed May 2011]; Ted C. Bergstrom, "Librarians and the Terrible Fix: Economics of the Big Deal," Serials 23, no. 2 (2010): 77-82.

11. A consortium is a group of libraries that license products as a to achieve price discounts or other desirable license terms. A site license is a license between an individual university and a publisher.

12. Sharon Farb, "Negotiating Use, Persistence, and Archiving: A Study of Academic Library and Publisher Perspectives on Licensing Digital Resources" (PhD diss., University of California, Los Angeles, 2006) ProQuest (AAT 3226006); Amy Hatfield, "Content Analysis of Restrictive Publisher Copyright Policies for Electronic Reserves" Journal of Interlibrary Loan, Document Delivery $\mathcal{E}$ Information Supply 11, no. 3 (2001): 81-92.

13. Farb, "Negotiating Use, Persistence, and Archiving"; Sharon Farb, "Libraries, Licensing and the Challenge of Stewardship," First Monday 11, no. 7 (2006), available online at http://firstmonday. org/issues/issue11_7/farb/index.html [accessed 1 June 2010 ]; Mary M. Case, "A Snapshot in Time: ARL Libraries and Electronic Journal Resources," ARL Newsletter XX, no. 235 (Aug. 2004): 1-10, available online at www.arl.org/resources/pubs/br/asit.shtml [accessed 1 June 2010 ].

14. Trisha L. Davis and Celeste Feather, "The Evolution of License Content," in Electronic Resource Management in Libraries: Research and Practice, eds. Holly Yu and Scott Breivold (Hershey, Pa.: Hershey Information Science Reference, 2008); Jim Stemper and Susan Barribeau,"Perpetual Access to Electronic Journals: A Survey of One Academic Research Library's Licenses," Library Resources \& Technical Services 50, no. 2 (Apr. 2006): 91.

15. Eschenfelder, Desai, and Downey, "The Pre-Internet Downloading Controversy."

16. Farb, "Negotiating Use, Persistence, and Archiving," 151.

17. Harris, Licensing Digital Content.

18. For example, the Liblicense model license suggests that libraries claim that "The Licensee and the Authorized Users may access or use the Licensed Materials in ways that are consistent with...the Copyright Act of 1976 (17 U.S.C. § 101, et seq.) ... including the Copyright Act's limitations on exclusive rights provisions." Similarly, the ICOLC 2004 statement urges that "These [copyright] exceptions, which take library reproduction and educational uses seriously, are to stay intact in the electronic environment."

19. Eschenfelder, Desai, and Downey, "The Pre-Internet Downloading Controversy."

20. Farb, "Libraries, Licensing and the Challenge of Stewardship," 17.

21. Farb, "Negotiating Use, Persistence, and Archiving," 144.

22. Farb, "Negotiating Use, Persistence, and Archiving," 102.

23. CLIR, "Liblicense Model License Agreement \& Commentary."

24. Farb, "Negotiating Use, Persistence, and Archiving," 145.

25. Davis and Feather, "The Evolution of License Content."

26. Section 108 Study Group Report (Washington, D.C.: United States Copyright Office and National Digital Information Infrastructure and Preservation Program Library of Congress, 2008). The rules governing ILL stem from Section 108 (d) and (e) of U.S. Copyright Law, but much dayto-day ILL practice is governed by the American Library Association's Interlibrary Loan Code for the United States. This guideline limits the number of copies of articles a library can request within a 5 -year period and places recordkeeping requirements on lenders and receivers. According to the Section 108 report, these guidelines are designed, in part, to preclude ILL from replacing journal subscriptions.

27. Anne Okerson to the Liblicense-L mailing list, July 13, 1997, "Results of Straw Poll on ILL in Electronic Licenses," available online at www.library.yale.edu/ llicense/straw.html [accessed 1 June 2010 ].

28. Case, "A Snapshot in Time."

29. Davis and Feather, "The Evolution of License Content." 
30. Farb, "Negotiating Use, Persistence, and Archiving"; Farb, "Libraries, Licensing and the Challenge of Stewardship."

31. CIC, "CIC Standardized Agreement Language."

32. STM, "STM Statement Document Delivery."

33. Section 108, “Study Group Report," 101.

34. Anne K. Beaubien, "ARL White Paper on Interlibrary Loan," Association of Research Libraries, available online at www.arl.org/bm doc/ARL_white_paper_ILL_june07.pdf [accessed May 2011].

35. Davis and Feather, "The Evolution of License Content."

36. CIC, "CIC Standardized Agreement Language"; CLIR, “Liblicense Model License Agreement \& Commentary."

37. Andrew Albanese, "Battle Brews Over E-Reserves," Library Journal, May 15, 2005, available online at www.libraryjournal.com/article/CA601047.html [accessed 1 June 2010]; Andrew Albanese, "A Failure to Communicate: In a lawsuit against Georgia State University over E-reserves, Scholarly Publishing Faces a Defining Moment," Publishers Weekly, June 14, 2010, available online at www.publishersweekly.com/pw/by-topic/industry-news/publisher-news/article/43500-a-failureto-communicate.html [accessed 1 June 2010 ]; Scott Carlson, "Legal Battle Brews Over Texts on Electronic Reserve at U. of California Libraries," Chronicle of Higher Education, April 22, 2005, available online at http://chronicle.com/article/Legal-Battle-Brews-Over/35248 [accessed 1 June 2010 ].

38. Debate exists within the library community about whether more explicit guidelines should be created. Some seek a more risk-averse option with recommended amounts and time periods. Others argue that only the four fair use factors should drive reserves decisions (Austin, 2005; ARL, 2004).

39. D. Goodman to the Liblicense-L listserv, November 21, 2000, "Including eReserve Provisions in Licensing Contracts," available online at www.library.yale.edu/ llicense/ListArchives/0011/ msg00023.html [accessed 1 June 2010 ].

40. Copyright Clearance Center (CCC), “Using Electronic Reserves: Guidelines and Best Practices for Copyright Compliance," available online at www.copyright.com/media/pdfs/UsingElectronic-Reserves.pdf [accessed 1 June 2010 ].

41. Hatfield, "Content Analysis."

42. Davis and Feather, "The Evolution of License Content"; Farb, "Negotiating Use, Persistence, and Archiving."

43. CLIR, "Liblicense Model License Agreement \& Commentary"; CIC, "CIC Standardized Agreement Language."

44. Chris Flegg, "Newswire Opinion: Libraries Clash with Harvard Business Publishing on Deep-Linking," Library Journal Online (Aug. 31, 2009), available online at www.libraryjournal. com/article/CA6678797.html [accessed 1 June 2010 ].

45. CLIR, "Liblicense Model License Agreement \& Commentary."

46. CIC, "CIC Standardized Agreement Language"; Section 7b: Course Management Systems, "Copies of such items shall be deleted by the Licensee when they are no longer required for such purpose."

47. Bergstrom, Courant, and McAfee, "Big Deal Contract Project"; Bergstrom, "Librarians and the Terrible Fix."

48. Ted C. Bergstrom, e-mail message to author, 2011.

49. The older license may include some attractive terms that the library desires to keep. This can discourage renegotiation of use terms and keep older terms present in newer licenses.

50. Kimberly A. Neuendorf, The Content Analysis Guidebook (Thousand Oaks: Sage, 2002)

51. Contact the first author for a full copy of the codebook including coding rules.

52. Neuendorf, The Content Analysis Guidebook.

53. Deen G. Freelon, "ReCal: Intercoder Reliability Calculation as a Web Service," International Journal of Internet Science 5, no. 1 (2010):20-33.

54. W. James Potter and Deborah Levine-Donnerstein, "Rethinking Validity and Reliability in Content Analysis," Journal of Applied Communication Research 27, no. 3 (1999): 258-65; Neuendorf, The Content Analysis Guidebook.

55. Katherine J. Klein, Fred Dansereau, and Rosalie J. Hall, "Level Issues in Theory Development, Data Collection and Analysis," Academy of Management Review 19, no. 2 (1994): 195-229.

56. Scott, Institutions and Organizations.

57. Klein, Dansereau, and Hall, "Level Issues in Theory Development, Data Collection and Analysis."

58. Note that we cannot make any claims about T\&F because the sample did not contain any T\&F consortia licenses.

59. Klein, Dansereau, and Hall, "Level Issues in Theory Development, Data Collection and 
Analysis."

60. Davis and Feather, "The Evolution of License Content."

61. Farb, "Negotiating Use, Persistence, and Archiving," 148.

62. Farb, "Negotiating Use, Persistence, and Archiving," Farb, "Libraries, Licensing and the Challenge of Stewardship," Davis and Feather, "The Evolution of License Content."

63. Davis and Feather, "The Evolution of License Content."

64. Farb, "Negotiating Use, Persistence, and Archiving," Farb, "Libraries, Licensing and the Challenge of Stewardship."

65. Davis and Feather, "The Evolution of License Content."

66. Lewis G. Liu, "Economics of Scholarly Publishing: Exploring the Causes of Subscription Price Variations of Scholarly Journals in Business Subject Specific Areas," Library Quarterly 81, no. 2 (2011):211-32.

67. John Schwartz, "Open-Access Advocate Is Arrested for Huge Download," New York Times Online (July 19, 2011), available online at www.nytimes.com/2011/07/20/us/20compute.html [accessed 1 June 2010 ].

68. Gayle Baker and Carol Tenopir, "Managing the Unmanageable: Systematic Downloading of Electronic Resources by Library Users," Journal of Library Administration 44, no. 3/4 (2006): 11-24; Heather Tones White, "Electronic Resources Security: A look at Unauthorized Users," code\{4\}lib journal 12 (2010-12-21), available online at http://journal.code4lib.org/articles/4117 [accessed 1 June 2010 ].

69. United States of America v. Aaron Swartz, No. 11-cr-01260 (D. Mass. Filed July 14, 2011). In the Swartz case, federal prosecutors referenced license terms in bringing the charge of computer fraud against the defendant. The charges were dependent (in part) on the existence of use restrictions in the license. 